\title{
Effect of pH on the bacterial community present in larvae and spat of Crassostrea gigas
}

\author{
Francisco A. Flores-Higuera ${ }^{1}$, Irasema E. Luis-Villaseñor ${ }^{2}$, Jesús A. Rochin-Arenas ${ }^{2}$ \\ Bruno Gómez-Gil ${ }^{3}$, José Manuel Mazón-Suástegui ${ }^{4}$ \\ Domenico Voltolina ${ }^{5}$ \& Diana Medina-Hernández ${ }^{4}$ \\ ${ }^{1}$ Posgrado en Ciencias en Recursos Acuáticos, Facultad de Ciencias del Mar \\ Universidad Autónoma de Sinaloa, Mazatlán, Sinaloa, México \\ ${ }^{2}$ Facultad de Ciencias del Mar, Universidad Autónoma de Sinaloa, Mazatlán, Sinaloa, México \\ ${ }^{3}$ CIAD, Mazatlán Unit for Aquaculture, Mazatlán, Sinaloa, México \\ ${ }^{4}$ Centro de Investigaciones Biológicas del Noroeste, La Paz, B.C.S., México \\ ${ }^{5}$ Centro de Investigaciones Biológicas del Noroeste, Laboratorio UAS-CIBNOR \\ Mazatlán, Sinaloa, México \\ Corresponding author: Irasema E. Luis-Villaseñor (irasemaluis@uas.edu.mx)
}

\begin{abstract}
Changes in marine environments, including $\mathrm{pH}$ changes, have been correlated to alterations in the physiology and disease susceptibility of cultured organisms at the early stages of development. In this study, high-throughput sequencing of the V3-V4 region of the 16S rRNA gene was performed to evaluate the bacterial biodiversity of Crassostrea gigas pediveliger larvae and spat under acidic stress compared to that of larvae at normal $\mathrm{pH}$ value. The evaluation was performed in an experimental system with continuous water flow and $\mathrm{pH}$ manipulation by $\mathrm{CO}_{2}$ bubbling to simulate acidification $(\mathrm{pH} 7.38 \pm 0.039)$, using the current ocean $\mathrm{pH}$ conditions $(\mathrm{pH} 8.116 \pm 0.023)$ as a reference. The results indicated that the bacterial communities associated with both pediveliger larvae and spat were modified in response to acidic conditions. The families Rhodobacteraceae and Campylobacteraceae were the most affected by the change in $\mathrm{pH}$, with increases in Vibrionaceae in pediveliger larvae and Planctomycetaceae and Phyllobacteriaceae in spat detected. The results of this study demonstrate that the bacterial communities associated with $C$. gigas pediveliger larvae and spat are responsive to changes in ocean acidification.
\end{abstract}

Keywords: Crassostrea gigas; pediveliger larvae; spat; ocean acidification; bacterial communities

\section{INTRODUCTION}

Stress factors that are directly caused by climate change are of great importance to the marine system, particularly the associated decrease in $\mathrm{pH}$ (Kroeker et al., $2010,2013)$. Ocean acidification is a result of the increase in $\mathrm{CO}_{2}$ levels and is an effect of global climate change (Caldeira \& Wickett, 2005), with a decrease of 0.3-0.5 pH units estimated to occur by the end of the century (IPCC, 2013). Alterations to the oceans, including changes in temperature and increases/ decreases in $\mathrm{CO}_{2}$ concentrations, disrupt the hostpathogen-environment balance, and have serious consequences for the survival of organisms (Burge et al., 2014). Ocean acidification affects organisms in variety of ways, including causing changes in calcium deposition, acid-base balance, energy distribution and metabolic equilibrium, embryonic development, growth and reproductive success (Allen \& Burnett, 2008; Parker et al., 2009), with these changes having been observed in crustaceans (Travers et al., 2009), corals (Haarvell et al., 2002) and mollusks (Cooley \& Doney, 2009).

Bivalve mollusks belong to a group of benthic and calcifying organisms that have been studied to understand the effect of acidification and climate change (Kurihara et al., 2007; Barton et al., 2012; Waldbusser et al., 2013). The cultivation of these orga-

Corresponding editor: Cesar Lodeiros 
nisms is a profitable economic activity throughout the world (Barton et al., 2015). The larval stage is among the most susceptible stages of mollusk development and is greatly affected by the chemistry of carbonates in seawater since mollusk larvae structure their larval shell (prodissoconch I) with the most soluble calcium carbonate (aragonite) (Stenzel, 1964).

The combination of stressors, such as low $\mathrm{pH}$ and exposure to bacterial pathogens, can have detrimental effects on the normal physiological processes of mollusks, including energy allocation and survival (Dorfmeier, 2012). Krause et al. (2012) reported that small changes in $\mathrm{pH}$ have a direct effect on the composition of the bacterial community, and the composition of microbial communities can be strongly affected and regulated by the external environment (Fierer \& Jackson, 2006).

Stress can alter microbial communities, causing an ecological succession and the appearance of pathogenic microorganisms that can cause disease (ZilberRosenberg \& Rosenberg, 2008; Asmani et al., 2016). Thus, it is necessary to study the bacterial communities associated with organisms that are under environmental stress. Therefore, the objective of this study was to analyze the microbiota of Crassostrea gigas larvae and juveniles grown at a low $\mathrm{pH}$ value (7.38) to test whether there is an effect on the structure of the resident communities of the host organism.

\section{MATERIALS AND METHODS}

\section{Acidification system of seawater}

The $\mathrm{pH}$ of seawater was manipulated following the $\mathrm{CO}_{2}$ bubbling method described by Fangue et al. (2010). Clean air was mixed with $\mathrm{CO}_{2}$ using Micro-Trak $101^{\circledR}$ to achieve a pH of 7.38 and Smart-Trak $100 \mathrm{C}^{\circledR}$ mass flow controllers (MFCs) to control the flow of $\mathrm{CO}_{2}$ and air, respectively (Sierra Instruments, Monterey CA, USA). The flow of $\mathrm{CO}_{2}$ and air were calibrated to be maintained at 5.00 and $2.63 \mathrm{~L} \mathrm{~min}^{-1}$, respectively. For the modified $\mathrm{pH}$ treatment $(\mathrm{pH} 7.38), \mathrm{CO}_{2}$ and air mixture were incorporated into filtered seawater $(1 \mu \mathrm{m}$ membrane and sterilized with ultraviolet light) in a mixing vessel rather than by bubbling these gases directly into the culture vessels. For the treatment under environmental conditions $(\mathrm{pH} 8.1$ ), the water was pumped directly from a $1,000 \mathrm{~L}$ reservoir of filtered seawater. The $\mathrm{CO}_{2}$-air and filtered seawater were mixed in a $19 \mathrm{~L}$ high-density polyethylene bucket using a submersible aquarium pump to provide vigorous circulation, and a Venturi device was used to direct the filtered seawater through a small orifice, creating negative pressure that aspirated the gas mixture into a very fine stream of bubbles for efficient mixing.

\section{Experimental design}

Pediveliger larvae of Crassostrea gigas Thunberg, 1793 (eyespots and active foot) with an average initial size of $335 \pm 6 \mu \mathrm{m}$ were subjected to two $\mathrm{pH}$ treatments (8.1 and 7.38). Larvae were placed in 2 inch PVC tubes with a $180 \mu \mathrm{m}$ mesh Nitex ${ }^{\mathrm{MR}}$ bottom, without substrate, allowing the pediveliger larvae to attach to the mesh bottom and the walls of the tube. The larvae were seeded at an initial density of 5 larvae $\mathrm{mm}^{-2}$, and the tubes were placed in $3 \mathrm{~L}$ plastic containers in triplicate, with a continuous downwelling-type flow of seawater $\left(0.5 \mathrm{~L} \mathrm{~min}^{-1}\right)$ that had been filtered through a $1 \mu \mathrm{m}$ membrane and sterilized by UV radiation, with a temperature of $25 \pm 1{ }^{\circ} \mathrm{C}$ and a salinity of 40 . The larvae were incubated for $24 \mathrm{~h}$, and the adhered organisms were directly quantified with the aid of magnifying glasses. The non-adhered organisms were placed in the tubes for an additional $24 \mathrm{~h}$, and samples were withdrawn for bacterial microbiota fingerprinting (16S rRNA metabarcoding) at 0,18 and $48 \mathrm{~h}$ after the start of the experiment.

A second experiment was performed by subjecting C. gigas spat $(1,450 \pm 220 \mu \mathrm{m})$ to two $\mathrm{pH}$ values $(8.1$ and 7.38) for seven days. Five hundred spat were placed in $3 \mathrm{~L}$ tanks in triplicate, and seed samples were withdrawn at 0,48 and $168 \mathrm{~h}$ to evaluate the bacterial community. The larvae were fed a diet of the haptophyte Isochrysis galbana at cell densities of 30,000 cells $\mathrm{mL}^{-1}$.

\section{Water quality}

The $\mathrm{pH}$ was measured daily with a Beckman $32 \mathrm{pH}$ m (accuracy \pm 0.001 ) that was calibrated before each use. The total alkalinity (TA) was estimated by acid titration using the volumetric method with a phenolphthalein endpoint and methyl orange as an indicator, with sulfuric acid $\left(\mathrm{H}_{2} \mathrm{SO}_{4}\right)$ used as the titrant (NOM-AA-361980). The salinity and temperature were determined with a YSI Model 85 multi-parameter measurement instrument. The chemical parameters of the carbonate system were calculated using the program $\mathrm{CO}_{2} \mathrm{SYS}$ v.01.05 (Lewis \& Wallace, 1998), applying the dissociation constant of Mehrbach et al. (1973) modified by Dickson \& Milero (1987). Information on the specific values of the elements of the carbonate system, salinity and temperature in the experimental treatments are summarized in Table 1.

\section{DNA isolation}

DNA was isolated from larvae and spat by filtering 10 $\mathrm{mL}$ of culture through a $300 \mu \mathrm{m}$ sieve, which was co- 
Table 1. Water chemistry parameters during the experiment. Salinity, temperature and $\mathrm{pH}$ were determined in samples of seawater from the experimental units every $48 \mathrm{~h}$. Total alkalinity $\left(\mu \mathrm{mol} \mathrm{kgSW}{ }^{-1}\right), p \mathrm{CO}_{2}(\mu \mathrm{atm}), \mathrm{HCO}_{3}\left(\mu \mathrm{mol} \mathrm{kgSW}^{-1}\right), \mathrm{CO}_{3}$ $\left(\mu \mathrm{mol} \mathrm{kgSW}{ }^{-1}\right), \Omega_{\text {cal }}$ and $\Omega_{\text {ar }}$ were calculated using the $\mathrm{CO}_{2} \mathrm{SYS}$ program. The data are presented as the means \pm standard deviation.

\begin{tabular}{|c|c|c|c|c|c|c|c|c|c|}
\hline & $\mathrm{T}^{\circ} \mathrm{C}$ & Salinity & $\mathrm{pH}$ & $\begin{array}{c}\text { TA } \\
\left(\mu \mathrm{mol} \mathrm{kgSW}^{-1}\right)\end{array}$ & $\begin{array}{l}p \mathrm{CO}_{2} \\
(\mu \mathrm{atm})\end{array}$ & $\begin{array}{c}\mathrm{HCO}_{3} \\
\left(\mu \mathrm{mol} \mathrm{kgS} \mathrm{W}^{-1}\right)\end{array}$ & $\begin{array}{c}\mathrm{CO}_{3} \\
\left(\mu \mathrm{mol} \mathrm{kgSW}^{-1}\right)\end{array}$ & $\Omega \mathrm{cal}$ & Sar \\
\hline Control $\mathrm{pH}$ & 10 & $40+08$ & $8.11 \pm 02$ & $2,030.42$ & $263.9 \pm 24.1$ & $1432.45 \pm 11.56$ & $231.86 \pm 22.15$ & $5.343 \pm 0.52$ & $3.536 \pm 0.34$ \\
\hline Low $\mathrm{pH}$ & $=1.0$ & $40 \pm 0.8$ & $7.384 \pm 04$ & $2,008.49$ & $1,864.46 \pm 234.0$ & $1,865.29 \pm 12.87$ & $55.96 \pm 5.42$ & $1.29 \pm 0.13$ & $0.853 \pm 0.09$ \\
\hline
\end{tabular}

llected in $1.5 \mathrm{~mL}$ sterile tubes. For juveniles, 50 organisms were collected. All of the samples were washed with sterile seawater followed by the addition of $1 \mathrm{~mL}$ of $96 \%$ ethanol, after which the samples were stored at $-20^{\circ} \mathrm{C}$.

DNA was extracted using a combination of lysis buffer and a commercial kit DNA purification kit (Promega) following the manufacturer's instructions. The $C$. gigas larvae and spat were homogenized by mechanical disruption and incubated for $1 \mathrm{~h}$ at $37^{\circ} \mathrm{C}$ with a lysis buffer containing Tris-EDTA-SDS (100 $\mathrm{mM} \mathrm{NaCl}, 50 \mathrm{mM}$ Tris [pH 8], $100 \mathrm{mM}$ EDTA [pH 8.0], sodium dodecyl sulfate $1 \%$ and $100 \mu \mathrm{L}$ of lysozyme $\left(50 \mathrm{mg} \mathrm{mL}^{-1}\right)$ ). The homogenized sample was then incubated for $12 \mathrm{~h}$ at $65^{\circ} \mathrm{C}$ with $20 \mu \mathrm{L}$ of proteinase $\mathrm{K}\left(20 \mathrm{mg} \mathrm{mL}^{-1}\right)$. Following lysis, $100 \mu \mathrm{L}$ of $5 \mathrm{M} \mathrm{NaCl}$ was added, the mixture was stirred, and 80 $\mu \mathrm{L}$ of a CTAB $/ \mathrm{NaCl}$ solution $(10 \% \mathrm{CTAB}$ in $0.7 \mathrm{M}$ $\mathrm{NaCl}$ ) was added and incubated at $65^{\circ} \mathrm{C}$ for $10 \mathrm{~min}$. Followed by the extraction of DNA with the kit DNA purification Kit (Promega).

\section{Library preparation and Illumina MiniSeq sequen- cing}

Twenty-five nanograms of DNA was used to generate amplicons spanning the V3 and V4 hypervariable regions of the bacterial 16S rRNA gene using the following primers: F-V3f 5'-TCG TCG GCA GCG TCA GAT GTG TAT AAG AGA CAG ACY CCT ACG GGR GGC AGC AG-3' and V4r 5'-GTC TCG TGG GCT CGG AGA TGT GTA TAA GAG ACA GGA CTA CHV GGG TAT CTA ATC C-3' (Klindworth et al., 2013). Subsequently, the purified amplicon was used as template to amplify the $\mathrm{V} 3$ region of the 16S rRNA gene using the following primers: forward 5'-TCG TCG GCA GCG TCA GAT GTG TAT AAG AGA CAG ACY CCT ACG GGR GGC AGC AG-3' and reverse 5'-GTC TCG TGG GCT CGG AGA TGT GTA TAA GAG ACA GTT ACC GCG GCT GCT GGC AC-3'. The total length of the final amplicon was $\sim 300 \mathrm{bp}$ (Huse et al., 2008).

Indexed adapters were added to the ends of the $16 \mathrm{~S}$ rRNA gene amplicons via limited-cycle PCR. The obtained DNA libraries were fluorometrically quantified using a Qubit dsDNA High Sensitivity Assay kit (Life Technologies). Subsequently, the DNA libraries were multiplexed and loaded onto an Illumina MiniSeq instrument (Illumina Biosystems, USA) following the manufacturer's instructions for $2 \times 150$ paired-end sequencing.

\section{Data analysis}

The sequences were decompressed, cleaned, assembled and converted to FASTA format. First, the data sequences were filtered to remove the forward and reverse primers and the barcode sequences. To minimize the effects of random sequencing errors, lowquality $(<\mathrm{Q} 20)$ fragments and sequences shorter than $150 \mathrm{bp}$ were removed, as well as sequences that contained any undetermined nucleotides $(\mathrm{N})$ and sequences $>150$ bp. Following denoising and chimera sequence removal, operational taxonomic units (OTUs) were classified using the EzBiocloud classifier (Yoon et al., 2017). The $\alpha$-diversity indices of the bacterial communities (Shannon, Simpson, evenness indices) were calculated using PAST 3.0 (Hammer et al., 2001). The $\beta$-diversity of bacterial communities associated with $C$. gigas pediveliger larvae and spat were analyzed with non-metric multidimensional scaling (NMDS) plots using PAST 3.0 (Hammer et al., 2001). The abundances of specific taxa in the bacterial communities were visualized used a shaded plot with a dendrogram representing Bray-Curtis similarities between bacterial taxa and the $\mathrm{pH}$ treatment.

\section{RESULTS}

\section{Sequencing}

The high-throughput sequencing analysis yielded 157,070 sequences for the 25 samples of oysters analyzed, which were assigned to 2,868 OTUs, including 1,578 OTUs for spat (Archaea, 0; Bacteria, 1,533; and Eukarya 45) and 1,355 OTUs for larvae (Archaea, 0; Bacteria, 1,290; and Eukarya, 65). Phylogenetic analysis of the sequences using the EzBiocloud classifier identified 14 phyla present in the 

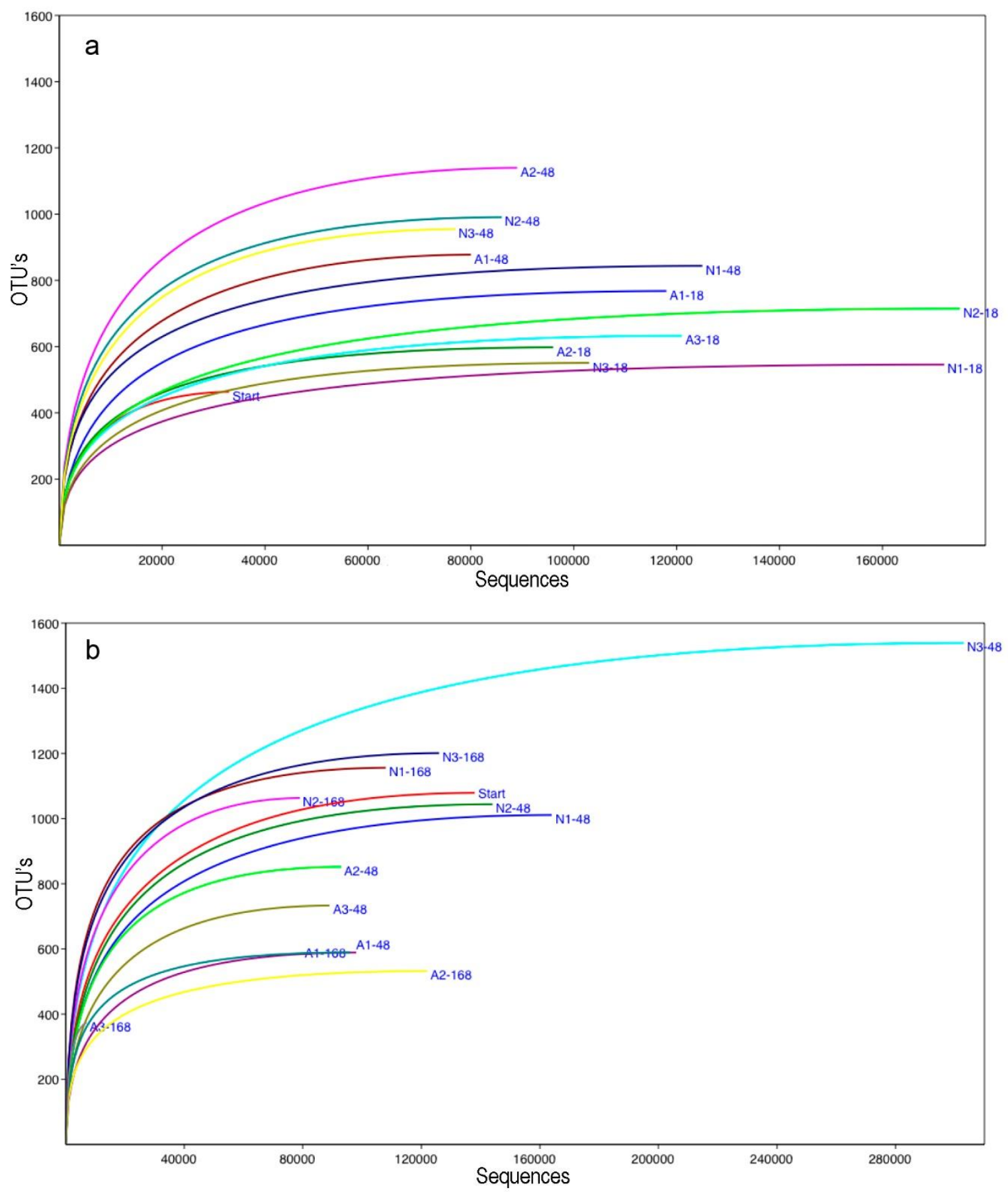

Figure 1. Rarefaction curves of the bacterial communities based on the 16S rRNA gene sequences generated using MiniSeq Illumina sequencing. a) Samples of pediveliger larvae, b) samples of a spat of Crassostrea gigas.

Crassostrea gigas larvae and spat samples (Acidobacteria, Actinobacteria, Bacteroidetes, Calditrichaeota, Chlamydiae, Chloroflexi, Chlorobi, Cyanobacteria, Firmicutes, Parcubacteria, Peregrinibacteria, Planctomycetes, Proteobacteria, and TM6). The results of a rarefaction analysis were of the OTUs suggested that the sequencing depth was adequate (Fig. 1).

\section{Bacterial communities in pediveliger larvae}

The Proteobacteria phylum dominated in pediveliger larvae with $82.97 \%$ of the OTUs; Alphaproteobacteria and Gammaproteobacteria were the most dominant classes with 52.15 and $22.29 \%$, respectively. The $\beta$ diversity analysis of all datasets showed that bacterial diversity changed after $18 \mathrm{~h}$ and varied depending on 

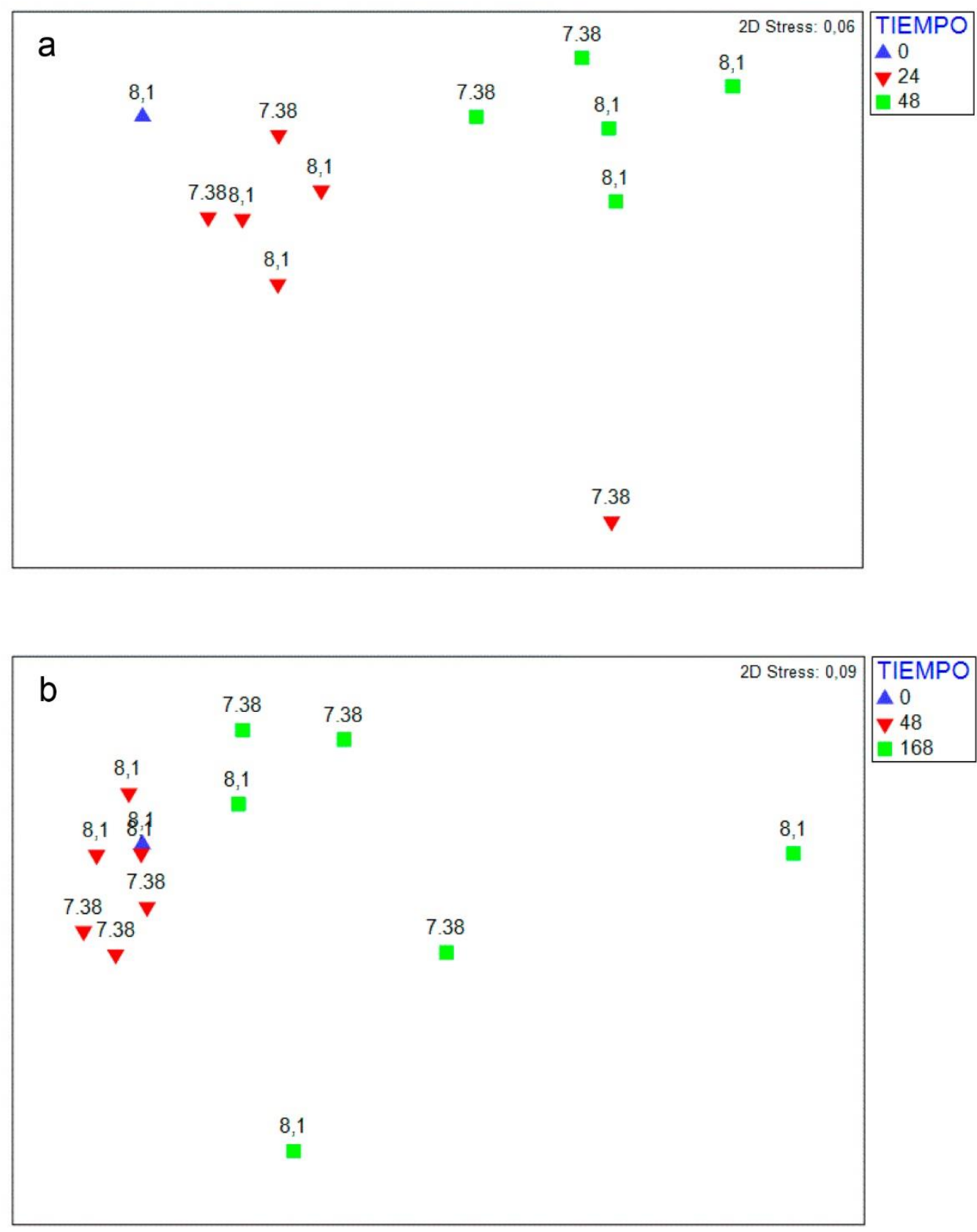

Figure 2. Nonmetric multidimensional scaling (NMDS) plots of the bacterial community structure of a) larvae and b) spat of Crassostrea gigas based on pairwise similarity estimate (Algorithm Bray-Curtis). Labels 8.1 and 7.38 indicate the $\mathrm{pH}$ treatment and the different culturing times (Start $(\boldsymbol{\Delta}), 18 \mathrm{~h}(\bullet)$, and $48 \mathrm{~h}(\square)$ ), for larvae; and Start $(\boldsymbol{\Delta}), 48 \mathrm{~h}(\boldsymbol{\nabla})$ and 168 h ( $\square)$ for spat).

the $\mathrm{pH}$ value of the water. The NMDS analysis indicated that changes occurred from $0-18 \mathrm{~h}$ and after $48 \mathrm{~h}$, with a decrease observed in the number of families (Fig. 2a), as a reduction was observed in the percentages of the primary bacterial families present after $48 \mathrm{~h}$ of exposure to a low $\mathrm{pH}$ (7.38).
Rhodobacteraceae dominated the bacterial community of the pediveliger larvae, exhibiting a relative abundance of $56.20 \%$. Campylobacteraceae was the second most abundant family in all of the assayed samples and decreased in abundance between 18 and $48 \mathrm{~h}$ for pediveliger larvae. Vibrionaceae was the third most 


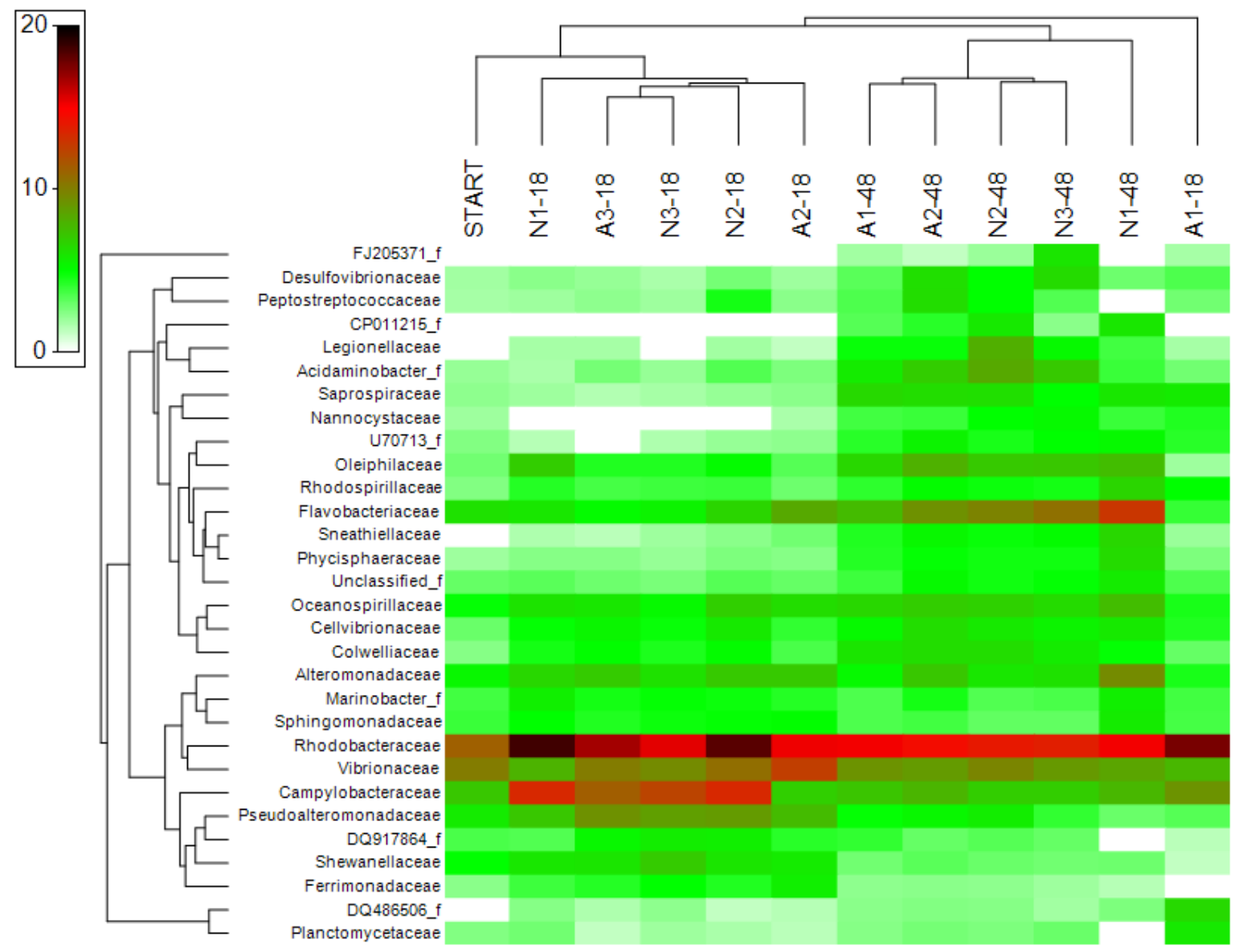

Figure 3. Shade plot of the 20 relevant families based on Bray-Curtis similarities in Crassostrea gigas pediveliger larvae cultured at different $\mathrm{pH}$ values (7.38 A1-A3: acidification, and 8.1 N1-N3: normal) at 0, 18 and $48 \mathrm{~h}$. Color bar in the left indicate percentage abundance.

Table 2. Diversity indices of bacterial communities associated with Crassostrea gigas pediveliger larvae and spat. A:

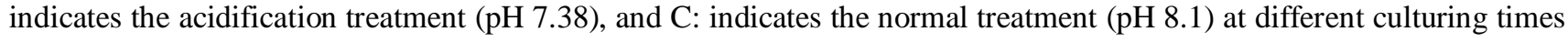
(pediveliger larvae: 0,18 and $48 \mathrm{~h}$; spat: 0,48 and $168 \mathrm{~h}$ ).

\begin{tabular}{|c|c|c|c|c|c|}
\hline \multicolumn{6}{|c|}{ Pediveliger larvae } \\
\hline \multirow[b]{2}{*}{ Diversity index } & & A & $\mathrm{C}$ & $\mathrm{A}$ & $\mathrm{C}$ \\
\hline & $0 \mathrm{~h}$ & $18 \mathrm{~h}$ & $18 \mathrm{~h}$ & $48 \mathrm{~h}$ & $48 \mathrm{~h}$ \\
\hline Shannon H & 4.05 & $3.85 \pm 0.22$ & $3.48 \pm 0.15$ & $4.71 \pm 0.39$ & $4.61 \pm 0.14$ \\
\hline Evenness $\mathrm{e}^{\wedge} \mathrm{H} / \mathrm{S}$ & 0.12 & $0.07 \pm 0.02$ & $0.05 \pm 0.01$ & $0.11 \pm 0.02$ & $0.11 \pm 0.01$ \\
\hline Simpson 1-D & 0.96 & $0.93 \pm 0.02$ & $0.91 \pm 0.01$ & $0.97 \pm 0.02$ & $0.97 \pm 0.01$ \\
\hline \multicolumn{6}{|c|}{ Spat } \\
\hline & & $\mathrm{A}$ & $\mathrm{C}$ & $\mathrm{A}$ & $\mathrm{C}$ \\
\hline & $0 \mathrm{~h}$ & $48 \mathrm{~h}$ & $48 \mathrm{~h}$ & $168 \mathrm{~h}$ & $168 \mathrm{~h}$ \\
\hline Shannon H & 4.49 & $3.79 \pm 0.41$ & $4.38 \pm 0.33$ & $3.98 \pm 0.65$ & $4.93 \pm 0.10$ \\
\hline Evenness $\mathrm{e}^{\wedge} \mathrm{H} / \mathrm{S}$ & 0.08 & $0.06 \pm 0.01$ & $0.07 \pm 0.01$ & $0.14 \pm 0.14$ & $0.13 \pm 0.01$ \\
\hline Simpson 1-D & 0.97 & $0.90 \pm 0.03$ & $0.95 \pm 0.02$ & $0.93 \pm 0.05$ & $0.98 \pm 0.00$ \\
\hline
\end{tabular}

abundant family and was detected at high levels the in $\mathrm{pH} 7.38$ treatment at $48 \mathrm{~h}(7.67 \%)$ (Fig. 3). The values of the biodiversity indices (Table 2) indicated a high level of diversity for all of the samples, with marked differences observed between the treatments for the Shannon and Simpson 1-D indices, with the highest 
values observed at $48 \mathrm{~h}$ in the $\mathrm{pH} 7.38$ treatment $(H=$ 4.709, $\left.S_{1-\mathrm{D}}=0.972\right)$.

\section{Bacterial communities in Crassostrea gigas spat}

The phylum Proteobacteria dominated spat, accounting for $83.3 \%$ of the OTUs, with $\alpha$-proteobacteria $(35.81 \%$ ) and Gammaproteobacteria $(34.88 \%)$ being the most dominant classes. The non-metric multidimensional scaling (NMDS) analysis was performed using the OTUs in each sample and was calculated to determine the similarity of the bacterial communities. The results revealed the presence of distinct microbial taxa associated with the $\mathrm{pH} 8.1$ (normal) and $\mathrm{pH} 7.38$ (acidification) samples after $168 \mathrm{~h}$ of exposure (Fig. 2b).

An increase in the relative abundances of specific taxa in the samples was observed at $168 \mathrm{~h}$ in compared to 0 and $48 \mathrm{~h}$, although the differences were not substantial. Rhodobacteraceae dominated the sequencing libraries from spat (relative abundance of $68.20 \%$ ), although the relative abundance was lower at $168 \mathrm{~h}$ $(49.28 \%)$ than at $0(84.7 \%)$ and $48 \mathrm{~h}(82.58$ and $84.10 \%$ at the normal $\mathrm{pH}$ and $\mathrm{pH} 7.38$, respectively).

The relative abundances of Planctomycetaceae and Phyllobacteriaceae increased at $168 \mathrm{~h}$ compared to that observed at 0 ( 2 and $0.71 \%)$ and $48 \mathrm{~h}(2.13$ and $0.45 \%)$, with the highest levels observed at $\mathrm{pH} 7.38$ (20.32 and 9.16\%), respectively. The families Hyphomicrobiaceae, Sphingomonadaceae, and Rhodospirillaceae were more abundant after $168 \mathrm{~h}$ than at $0 \mathrm{~h}$, representing more than $1 \%$ of the community (Fig. 4).

The values obtained for the biodiversity indices (Table 2) indicated high levels of diversity for all of the samples, with marked differences observed between the treatments for the Shannon and Simpson 1-D indices. In addition, the highest diversity values were observed in the samples from the normal $\mathrm{pH}\left(H=4.929, \mathrm{~S}_{1-\mathrm{D}}=\right.$ $0.978)$ compared to those from the acidic treatment $(\mathrm{H}$ $\left.=3.982, \mathrm{~S}_{1-\mathrm{D}}=0.926\right)$ at $168 \mathrm{~h}$.

\section{DISCUSSION}

In the present work, the bacterial communities of Crassostrea gigas pediveliger larvae and spat under $\mathrm{pH}$ stress were analyzed, simulating the conditions present in estuaries where oysters are grown and of a hatchery located in northwestern Mexico, where the water has been reported to have a $\mathrm{pH}$ of 7.4 (P. Danigo, pers. comm.). Although these oceanic $\mathrm{pH}$ values are not expected to be reached until the year 2300 (Caldiera \& Wickett, 2005; Doney et al., 2009) the effects of ocean acidification are already being observed in these oyster growing areas and hatcheries in northwest Mexico
(Páez-Osuna et al., 2016; Rodríguez-Quiroz et al., 2016) and in other parts of the world (Cai et al., 2011; Cornwall et al., 2013; Ginger et al., 2013).

The results of this study showed that the bacterial communities in both pediveliger larvae and spat were modulated when subjected to acidic conditions. The larvae exhibited a remarkably higher bacterial diversity at the lower $\mathrm{pH}$ value, whereas the effect was opposite in spat since a reduction in diversity was observed. Counterproductive effects have been observed in oyster larvae that affect their survival, growth and calcification (Barton et al., 2012, 2015; Kroeker et al., 2013; Waldbusser et al., 2015), and larvae with valves composed of aragonite are generally the most susceptible to dissolution under lower $\mathrm{pH}$ conditions (Ries et al., 2009; Kroeker et al., 2013). In this study, we observed an effect on the microbiota present in $C$. gigas larvae and spat that indicated a direct negative effect on some of the most dominant taxa. Oceanic acidification increases the colonization of pathogenic organisms in marine organisms because it increases the susceptibility of hosts by modifying the normal microbiota (Mouchka et al., 2010).

Microorganisms adapt quickly to environmental changes due to resistance gene transfer, even in a homeostatic environment (Ochman et al., 2000). Recently, $C$. gigas has faced new challenges to its survival, including the looming threat of ocean warming/acidification and the proliferation of pathogens. The decrease in $\mathrm{pH}$ was observed to have a negative effect on the bacterial community associated with both pediveliger larvae and spat, primarily affecting the relative abundance of Rhodobacteraceae, with that of Campylobacteraceae only affected in larvae. Rhodobacteraceae and Campylobacteraceae are considered to be susceptible to low $\mathrm{pH}$ values (Krause et al., 2012), resulting in alterations in their abundances. Similar trends were also observed in coral reefs (Witt et al., 2011). Rhodobacteraceae is considered to be an important bacterial lineage in marine environments, is naturally present in biofilms on flora and fauna (Elifantz et al., 2013). Campylobacteraceae has been shown to grow over a wide $\mathrm{pH}$ range and can survive in contaminated food and support stomach transit (Murphy et al., 2006; Reid et al., 2008). Bivalve mollusks harbor an abundant bacterial microbiota that modulates in response to environmental factors. The influence of the microbiota on the health of host organisms has been documented as a crucial aspect in the development of diseases (Ruby et al., 2004; Zhen et al., 2017). Asmani et al. (2016) indicated that normal larval microbiota in $C$. gigas is primarily composed of Rhodobacteraceae ( $\alpha$-Proteobacteria) and a few members of the family Vibrionaceae. 


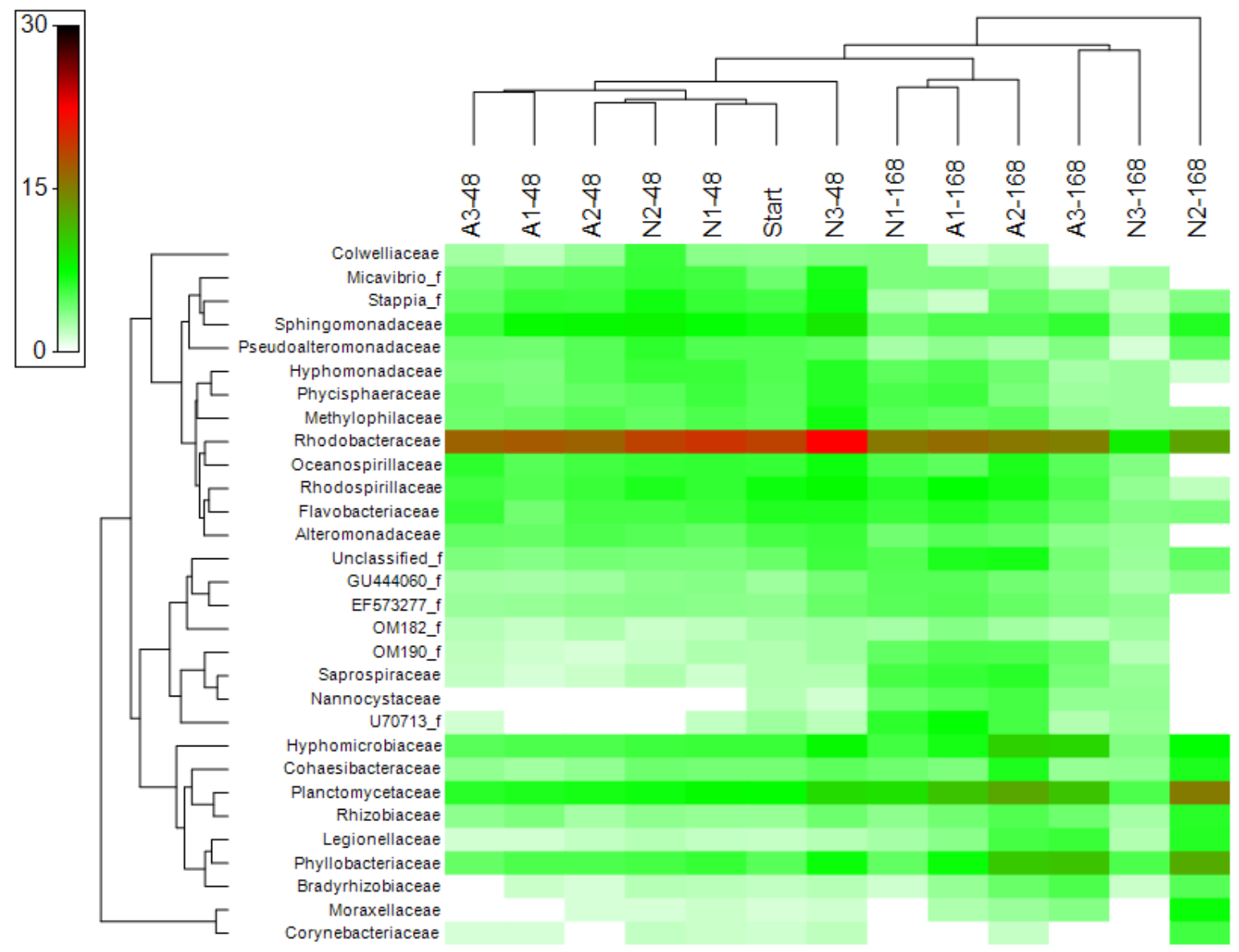

Figure 4. Shade plot of the 20 relevant families based on Bray-Curtis similarities in Crassostrea gigas spat cultured at different $\mathrm{pH}$ values (7.38 A1-A3: acidification; and 8.1 N1-N3: normal) at 0, 48 and $168 \mathrm{~h}$. Color bar in the left indicate percentage abundance.

In this study, an increase in Vibrionaceae at a low $\mathrm{pH}$ value in pediveliger larvae was observed after $48 \mathrm{~h}$ of culturing compared to the normal $\mathrm{pH}$ value but not in the initial samples. This increase represents a negative effect on the development larvae, since a primary problem facing the culture of bivalve mollusks is the appearance of larval vibriosis, which can cause high larval mortality (Sainz-Hernández \& MaedaMartínez, 2005; Travers et al., 2015; Asmani et al., 2016). Furthermore, an increase of the virulence of Vibrio tubiashii toward the blue mussel has been observed at low pH (Asplund et al., 2014) as well as an increase in the production of secondary metabolites and stress (Vega-Thurber et al., 2009). Similarly, an increase in Vibrionales in the seaweed Sargassum muticum (Aires et al., 2018) and corals (Meron et al., 2012) has been observed. However, not all bacterial groups are susceptible to low $\mathrm{pH}$, and only for those taxa that are key in the development of biofilms and are consider primary colonizers of marine environments, such as Rhodobacteraceae, has this effect been evidenced in bacterial communities present in seawater at lower pH (7.67) (Krause et al., 2012). The decrease in members of this family may have implications for the stability of these communities, as it has been shown to be an initial colonizing family of marine bacterial communities (Elifantz et al., 2013). Thus, this type of change in bacterial communities present in seawater can represent a risk for the development of the microbiota present in cultured organisms, since there is a direct relationship between the community present in the culture water and the microbiota of the organisms, as demonstrated by Trabal et al. (2014).

The families Planctomycetaceae and Phyllobacteriaceae exhibited the highest overall growth in a spat at pH 7.38 at $168 \mathrm{~h}$. However, the family Rhodobacteraceae decreased at low $\mathrm{pH}$ over the same period and under the same treatment. Thus, the community structure, diversity, and dominance of families were directly influenced by culturing time and $\mathrm{pH}$.

The results of this study demonstrate that bacterial communities change under low $\mathrm{pH}$ conditions. Specific 
bacterial taxa exhibited significant shifts in abundance under acidic conditions, such as Vibrionaceae and Planctomycetaceae, and the levels Rhodobacteraceae and Campylobacteraceae. Meron et al. (2011) reported an increase in bacteria that possess antimicrobial activity in coral maintained at a low $\mathrm{pH}$ of 7.6. It is interesting to note that most of these antimicrobial active bacterial belonged to the family Vibrionaceae, suggesting that this may be one of the mechanisms that allow these species to increase their distribution within the microbial community.

In summary, the results of this study demonstrate that the microbiota associated with $C$. gigas pediveliger larvae and spat are responsive to changes in acidifycation. The abundances of families such as Vibrionaceae and Planctomycetaceae exhibited signifi-cant changes under conditions of acidification and adverse effects toward other groups, including Rhodobacteraceae and Campylobacteraceae.

\section{ACKNOWLEDGMENTS}

The PROFAPI2015/158 funded this research. F.A. Flores-Higuera received doctoral fellowships from CONACYT (388861), and the results presented here are part of a doctoral thesis. The Acuacultura Robles S.P.R. de R.I. Company is thanked for the donation of the larvae for the experiments. Pablo MonsalvoSpenser is thanked for his logistical support during the experiments.

\section{REFERENCES}

Aires, T., Serebryakova, A., Viard, F., Serrão, E.A. \& Engelen, A.H. 2018. Acidification increases abundances of Vibrionales and Planctomycetia associated to a seaweed-grazer system: potential consequences for disease and prey digestion efficiency. PeerJ, 6: e4377.

Allen, S.M. \& Burnett, L.E. 2008. The effects of intertidal air exposure on the respiratory physiology and the killing activity of hemocytes in the Pacific oyster, Crassostrea gigas (Thunberg). Journal of Experimental Marine Biology and Ecology, 357:165171.

Asmani, K., Petton, B., Le Grand, J., Mounier, J., Robert, R. \& Nicolas, J.L. 2016. Establishment of microbiota in larval culture of Pacific oyster, Crassostrea gigas. Aquaculture, 464: 434-444.

Asplund, M.E., Baden, S.P., Russ, S., Ellis, P., Gong, N. \& Hernroth, B.E. 2014. Ocean acidification and hostpathogen interactions blue mussels, Mytilus edulis, encountering Vibrio tubiashii. Environmental Microbiology, 16(4): 1029-1039.
Barton, A., Waldbusser, G.G., Feely, R.A., Weisberg, S.B., Newton, J.A., Hales, B., Cudd, S., Eudeline, B., Langdon, C.J., Jefferds, I., King, T., Suhrbier, A. \& McLaughlin, K. 2015. Impacts of acidification on the coastal Pacific Northwest shellfish industry and adaptation strategies in response implemented. Oceanography, 28 (2): 146-159.

Barton, A., Hales, B., Waldbusser, G.G., Langdon, C. \& Feely, R.A. 2012. The Pacific oyster, Crassostrea gigas, shows negative correlation to naturally elevated carbon dioxide levels: implications for near-term ocean acidification effects. Limnology and Oceanography, 57: 698-710.

Burge, C.A., Eakin, C.M., Friedman, C.S., Froelich, B., Hershberger, P.K., Hofmann, E.E., Petes, L.E., Prager, K.C., Weil, E., Willis, B.L., Ford, S.E. \& Harvell, C.D. 2014. Climate change influences on marine infectious diseases: implications for management and society. Annual Review of Marine Science, 6: 249-277.

Cai, W.J., Hu, X., Huang, W.J., Murrell, M.C., Lehrter, J.C., Lohrenz, S.E., Chou, W.C., Zhai, W., Hollibaugh, J.T., Yongchen, W., Pingsan, Z., Xianghui, G., Gundersen, K., Dai, M. \& Gong, G.C. 2011. Acidification of subsurface coastal waters enhanced by eutrophication. Nature Geoscience, 4: 766-770.

Caldeira, K. \& Wickett, M.E. 2005. Ocean chemistry model predictions of changes from carbon dioxide emissions to the atmosphere and ocean. Journal of Geophysical Research, 110: 1-12.

Cooley, S.R. \& Doney, S.C. 2009. Anticipating ocean acidification's economic consequences for commercial fisheries. Environmental Research Letters, 4: 1-8.

Cornwall, C.E., Hepburn, C.D., McGraw, C.M., Currie, K.I., Pilditch, C.A., Hunter, K.A., Boyd, P.W. \& Hurd, C.L. 2013. Diurnal fluctuations in seawater $\mathrm{pH}$ influence the response of a calcifying macroalga to ocean acidification. Proceedings of the Royal Society, 280: 1-8.

Dickson, A.G \& Millero, F.J. 1987. A comparison of the equilibrium constants for the dissociation of carbonic acid in seawater media. Deep-Sea Research, 34: 17331743.

Doney, S.C., Fabry, V.J., Feely, R.A. \& Kleypas, J.A. 2009. Ocean acidification: the other $\mathrm{CO}_{2}$ problem. Annual Review of Marine Science, 1: 169-192.

Dorfmeier, E.M. 2012. Ocean acidification and disease: how will a changing climate impact Vibrio tubiashii growth and pathogenicity to Pacific oyster larvae? Master Thesis, University of Washington, School of Aquatic and Fishery Sciences, Washington.

Elifantz, H., Horn, G., Ayon, M., Cohen, Y. \& Minz, D. 2013. Rhodobacteraceae are the key members of the 
microbial community of the initial biofilm formed in eastern Mediterranean coastal seawater. FEMS Microbiology Ecology, 85: 348-357.

Fangue, N.A., O'Donnell, M.J., Sewell, M.A., Matson, P.G., MacPherson, A.C. \& Hofmann, G.E. 2010. A laboratory-based experimental system for the study of ocean acidification effects on marine invertebrate larvae. Limnology and Oceanography Methods, 8: 441-452.

Fierer, N. \& Jackson, R.B. 2006. The diversity and biogeography of soil bacterial communities. Proceedings of the National Academy of Sciences, 103: 626631.

Ginger, K.W.K., Vera, C.B.S., Dineshram, R., Deniss, C.K.S., Adela, L.J., Yu, Z. \& Thiyagarajan, V. 2013. Larval and post-larval stages of Pacific oyster (Crassostrea gigas) are resistant to elevated $\mathrm{CO}_{2}$. Plos One, 8(5): e64147.

Hammer, Ø., Harper, D.A.T. \& Ryan, P.D. 2001. PAST: Paleontological Statistics software package for education and data analysis. Palaeontologia Electronica, 4(1): 9 pp.

Harvell, C.D., Mitchell, C.E., Ward, J.R., Altizer, S., Dobson, A.P., Ostfeld, R.S. \& Samuel, M.D. 2002. Climate warming and disease risk for terrestrial and marine biota. Science, 296: 2158-2162.

Huse, S.M., Dethlefsen, L., Huber, J.A., Welch, D.M., Relman, D.A. \& Sogin, M.L. 2008. Exploring microbial diversity and taxonomy using SSU rRNA hypervariable tag sequencing. PLOS Genetics, 4(11): e1000255.

Intergovernmental Panel on Climate Change (IPCC). 2013. Climate change 2013: the physical science basis. In: Stocker, T.F., Qin, D., Plattner, G.-K., Tignor, M., Allen, S.K., Boschung, J., Nauels, A., Xia, Y., Bex, V. \& Midgley, P.M. (Eds.). Contribution of working group I to the fifth assessment report of the intergovernmental panel on climate change. Cambridge University Press, Cambridge.

Klindworth, A., Pruesse, E., Schweer, T., Peploes, J., Quast, C., Horn, M. \& Glöckner, F.O. 2013. Evaluation of general 16S ribosomal RNA gene PCR primers for classical and next-generation sequencingbased diversity studies. Nucleic Acids Research, 41(1): 1-11.

Krause, E., Wichels, A., Giménez, L., Lunau, M., Schilhabel, M.B. \& Gerdts, G. 2012. Small changes in $\mathrm{pH}$ have direct effects on marine bacterial community composition: a microcosm approach. Plos One, 7(10): e47035.

Kroeker, K.J., Kordas, R.L., Crim, R.N. \& Singh, G.G. 2010. Meta-analysis reveals negative yet variable effects of ocean acidification on marine organisms. Ecology Letters, 13: 1419-1434.
Kroeker, K.J., Kordas, R.L., Crim, R., Hendriks, I.E., Ramajo, L., Singh, G.S., Duarte, C.M. \& Gattuso, J.P. 2013. Impacts of ocean acidification on marine organisms: quantifying sensitivities and interaction with warming. Global Change Biology, 19: 18841896.

Kurihara, H., Kato, S. \& Ishimatsu, A. 2007. Effects of increased seawater $\mathrm{pCO}_{2}$ on early development of the oyster Crassostrea gigas. Aquatic Biology, 1: 91-98.

Lewis, E. \& Wallace, D.W.R. 1998. Program developed for $\mathrm{CO}_{2}$ system calculations. Carbon dioxide information analysis center, Oak Ridge National Laboratory, Tennessee.

Mehrbach, C., Culberson, C.H., Hawley, J.E. \& Pytkowicz, R.M. 1973. Measurement of the apparent dissociation constants of carbonic acid in seawater at atmospheric pressure. Limnology and Oceanography, 18: 897-907.

Meron, D., Rodolfo-Metalpa, R., Cunning, R., Baker, A.C., Fine, M. \& Banin, E. 2012. Changes in coral microbial communities in response to a natural $\mathrm{pH}$ gradient. The ISME Journal, 6: 1775-1785.

Meron, D., Atias, E., Iasur-Kruh, L., Elifantz, H., Minz, D., Fine, M. \& Banin, E. 2011. The impact of reduced $\mathrm{pH}$ on the microbial community of the coral Acropora eurystoma. The ISME Journal, 5: 51-60.

Mouchka, M.E., Hewson, I. \& Harvell, C.D. 2010. Coralassociated bacterial assemblages: current knowledge and the potential for climate-driven impacts. Integrative and Comparative Biology, 50: 662-674.

Murphy, C., Carroll, C. \& Jordan, K.N. 2006. Environmental survival mechanisms of the foodborne pathogen Campylobacter jejuni. Journal of Applied Microbiology, 100: 623-632.

Ochman, H., Lawrence, J.G. \& Groisman, E.A. 2000. Lateral gene transfer and the nature of bacterial innovation. Nature, 405: 299-304.

Páez-Osuna, F., Sanchez-Cabeza, J.A., Ruiz-Fernández, A.C., Alonso-Rodríguez, A.C.R., Cardoso-Mohedano, J.G., Flores-Verdugo, F.J., Cisneros-Mata, M.A., Carballo, J.L., Piñón-Gimate, A. \& Álvarez-Borrego, S. 2016. Environmental status of the Gulf of California: a review of responses to climate change and climate variability. Earth-Science Reviews, 162: 253-268.

Parker, L., Ross, P. \& O'Connor, W. 2009. The effect of ocean acidification and temperature on the fertilization and embryonic development of the Sydney rock oyster Saccostrea glomerata (Gould 1850). Global Change Biology, 15: 2123-2136.

Reid, A.N., Pandey, R., Palyada, K., Naikare, H. \& Stintzi, A. 2008. Identification of Campylobacter jejuni genes 
involved in the response to acidific $\mathrm{pH}$ and stomach transit. Applied and Environmental Microbiology, 74: 1583-1597.

Ries, J.B., Cohen, A.L. \& McCorkle, D.C. 2009. Marine calcifiers exhibit mixed responses to $\mathrm{CO}_{2}$-induced ocean acidification. Geology, 37: 1131-1134.

Rodríguez-Quiroz, G., García-Ulloa, M., DomínguezOrozco, A.L., Valenzuela-Hernández, T.N., NavaPérez, E. \& Góngora-Gómez, A.M. 2016. Relación del crecimiento, condición y supervivencia del ostión del Pacífico Crassostrea gigas y las variables ambientales, cultivado en suspensión en el sistema lagunar Navachiste-Macapule, Sinaloa, México. Revista de Biología Marina y Oceanografía, 51(3): 541-551.

Ruby E., Henderson, B. \& Mcfall-Ngai, M. 2004. Microbiology. We get by with a little help from our (little) friends. Science, 303: 1305-1307.

Stenzel, H.B. 1964. Oysters: composition of the larval shell. Science, 145: 155-156.

Sainz-Hernández, J.C. \& Maeda-Martínez, A.N. 2005. Sources of Vibrio bacteria in mollusk hatcheries and control methods: a case study. Aquaculture Research, 36: 1611-1618.

Trabal, N.F., Mazón-Suástegui, J.M., Vázquez-Juárez, R., Ascencio-Valle, F. \& Romero, J. 2014. Changes in the composition and diversity of the bacterial microbiota associated with oyster (Crassostrea corteziensis, Crassostrea gigas, and Crassostrea sikamea) during commercial production. FEMS Microbiology Ecology, 88: 69-83.

Travers, M.A., Miller, K.B., Roque, A. \& Friedman, C.S. 2015. Bacterial diseases in marine bivalves. Journal of Invertebrate Pathology, 131: 11-31.

Travers, M.A., Basuyaux, O., LeGoic, N., Huchette, S., Nicolas, J.L., Koken, M. \& Paillard, C. 2009. Influence of temperature and spawning effort on Haliotis tuberculate mortalities caused by Vibrio harveyi: an example of emerging vibriosis linked to global warming. Global Change Biology, 15: 13651376.

Received: 3 August 2018; Accepted: 23 March 2019
Vega-Thurber, R., Willner-Hall, D., Rodriguez-Mueller, B., Desnues, C., Edwards, R.A., Angly, F., Dinsdale, E., Kelly, L. \& Rohwer, F. 2009. Metagenomic analysis of stressed coral holobionts. Environmental Microbiology, 11(8): 2148-2163.

Waldbusser, G.G., Hales, B., Langdon, C.J., Haley, B.A., Schrader, P., Brunner, E.L., Gray, M.W., Miller, C.A. \& Gimenez, I. 2015. Saturation-state sensitivity of marine bivalve larvae to ocean acidification. Nature Climate Change, 5: 273-280.

Waldbusser, G.G., Brunner, E.L., Haley, B.A., Hales, B., Langdon, C.J. \& Prahl, F.G. 2013. A developmental and energetic shell oyster larval basis linking formation sensitivity to acidification. Geophysical Research Letters, 40: 2171-2176.

Witt, V., Wild, C., Anthony, K.R.N., Diaz-Pulido, G. \& Uthicke, S. 2011. Effects of ocean acidification on microbial community composition of, and oxygen fluxes through, biofilms from the Great Barrier Reef. Environmental Microbiology, 13: 2976-2989.

Yoon, S.H., Ha, S.M., Kwon, S., Lim, J., Kim, Y., Seo, H. \& Chun, J. 2017. Introducing EzBioCloud: a taxonomically united database of $16 \mathrm{~S}$ rRNA and whole genome assemblies. International Journal of Systematic and Evolutionary Microbiology, 67: 16131617.

Zhen, L., Nicolae, V.V., Akileh, R. \& Liu, T. 2017. A brief review of oyster-associated microbiota. Microbiology Research Journal International, 20(5): 1-14.

Zilber-Rosenberg, I. \& Rosenberg, E. 2008. Role of microorganisms in the evolution of animals and plants: the hologenome theory of evolution. FEMS Microbiology Letters, 32: 723-735. 